\title{
Pseudomonas syringae pv. tabaci in papaya seedlings
}

\author{
Luís Otávio S. Beriam¹, Irene M.G. Almeida, Suzete A.L. Destéfano, Eunice Grabert, Denise M. Balani, Mariana \\ Ferreira, Júlio Rodrigues Neto
}

Instituto Biológico, Caixa Postal 70, 13001-970, Campinas, SP, Brazil

${ }^{1}$ Correponding author <beriam @biologico.sp.gov.br>

Data de chegada: 01/09/04. Aceito para publicação: 23/06/05.

\begin{abstract}
Beriam, L.O.S.; Almeida, I.M.G.; Destéfano, S.A.L.; Grabert, E.; Balani, D.M.; Ferreira, M.; Rodrigues Neto, J. Pseudomonas syringae pv. tabaci in papaya seedlings. Summa Phytopathologica, v.32, p. 21-26, 2006.

The natural occurrence of Pseudomonas syringae pv. tabaci causing leaf spot symptoms in papaya seedlings is reported. The pathogen was identified through biochemical, physiological, serological, and molecular assays and artificial inoculations in papaya plants. It was also shown that the strains were pathogenic to bean and tobacco plants. The restriction patterns obtained with Afa I, Alu I, Dde I, Hae

III, Hpa II, Hinf I, Sau 3A I and Taq I of the PCR-RFLP of 16S-23S DNAr were identical to the P. s. pv. tabaci patterns. Primers corresponding to $h r p L$ gene of $P$. syringae were also tested and the results grouped the papaya strains with $P s$. pv. tabaci. Bacterial strains were deposited at Coleção de Culturas IBSBF, Instituto Biológico, Campinas, Brazil, under access numbers 1687 and 1822.
\end{abstract}

Additional keywords: papaya bacterial diseases, 16S-23S rDNA.

\section{RESUMO}

Beriam, L.O.S.; Almeida, I.M.G.; Destéfano, S.A.L.; Grabert, E.; Balani, D.M.; Ferreira, M.; Rodrigues Neto, J. Pseudomonas syringae pv. tabaci em plântulas de mamoeiro. Summa Phytopathologica, v.32, p. 21-26, 2006.

É relatada a ocorrência natural de Pseudomonas syringae pv. tabaci causando sintomas de lesões foliares em plântulas de mamoeiro. $\mathrm{O}$ patógeno foi identificado por meio de testes bioquímicos, fisiológicos, serológicos e moleculares, além de ensaios de patogenicidade em plantas de mamoeiro, feijoeiro e fumo. Os padrões de restrição obtidos com as enzimas Afa I, Alu I, Dde I, Hae III, Hpa II, Hinf I, Sal 3A I e Taq I, utilizando-se a técnica de PCR-RLFP da região espaçadora 16S-23S do

Palavras-chave adicionais: bacteriose do mamoeiro, 16S-23S DNAr.
DNA ribossômico, foram idênticos àqueles apresentados para $P$. s. pv. tabaci. Primers correspondentes ao gene hrpL de $P$. syringae foram também testados e os resultados obtidos permitiram agrupar as linhagens isoladas de mamão com $P$. s. pv. tabaci. Linhagens bacterianas estão depositadas na coleção de culturas IBSBF, Instituto Biológico, Campinas, sob n. 1687 e 1822.
Brazil is the most important producer of fresh papaya (Carica papaya $\mathrm{L}$.) in the world, with a planted area of approximately 30,000 ha and is responsible for an annual production of 1,6 millions of ton of fresh papaya. The main region of exportation is located at the State of Espírito Santo which represents 87.6\% of the total exported fruits (24).

Papaya production may be affected by many factors such as the occurrence of phytopathogenic agents, like bacterial diseases, which could causes serious losses. Several bacterial species could infect papaya plants. In 1956, Robbs (19) reported a bacterial disease in Brazil causing symptoms of water soaked and angular spots on papaya leaves, naming the pathogen as Pseudomonas caricapapayae. Nelson \& Alvarez (13) described in 1976 a disease causing symptoms of "purple stain" in papaya fruits in Hawaii, which causal agent was identified as Erwinia herbicola. In 1979, Erwinia cypripedii causing black rot on seedlings, trees and fruits of papaya was observed in Taiwan (10). Two other bacterial diseases caused by Erwinia spp. and called "erwinia mushy canker" and "erwinia decline" occurring respectively in trees and seedlings of papaya were 
reported by Trujillo \& Schroth (23) in Hawaii. Other diseases induced by Erwinia sp. were also described by Webb (25) in Saint Croix, U.S. Virgin Islands, causing canker on papaya trees and by Frossard et al. (5) who reported a papaya disease caused by Erwinia belonging to the "amylovora" group.

An Erwinia strain associated with Papaya Ringspot Virus inducing symptoms of bud rot and causing severe damage on papaya plants was described by Robbs et al. (20) in the South of Brazil and further investigations identified it as E. carotovora subsp. atroseptica ${ }^{1}$.

Recently, the causal agents of the diseases described by Trujillo \& Schroth (23), Web (25) and Frossard et al. (5) were identified as a new bacterial species named Erwinia papayae (6).

Enterobacter cloacae was another bacterial species described in papaya, inducing symptoms of internal yellowing of fruits in Hawaii (14). Strains of E. cloacae were also isolated from papaya fruits in Brazil ${ }^{1}$.

In September 2001 seedlings of papaya cv. Golden showing symptoms of brown colored leaf spots, with, sometimes surrounded by a diffuse chlorotic halo, that may progress to large necrotic areas, were observed in commercial nurseries located at Li- nhares county, State of Espírito Santo, Brazil. Bacterial strains that belong to Pseudomonas syringae group (LOPAT Ia) were isolated from these necrotic lesions in a preliminary study (2).

The objective of the present study was to identify these papaya strains at pathovar level through biochemical, serological, pathological, and molecular tests.

\section{MATERIAL ANDMETHODS}

\section{Pathogen isolation}

Small pieces of diseased leaf tissues were excised from the lesions and macerated in sterile distilled water. The resultant suspension was streaked on plates containing Nutrient Agar (NA) (11) or King's B (9) media and then incubated at $28^{\circ} \mathrm{C}$ for $48 \mathrm{~h}$. Individual colonies were cultured and used in hypersensitivity tests on tobacco leaves.

\section{Bacterial strains}

Besides the papaya isolates, other bacterial strains were included in this study for comparative purposes (Table 1). The strains were recovered from freeze-dried cultures and grown on NA at $28^{\circ} \mathrm{C}$ for $48 \mathrm{~h}$.

Table 1. Bacterial strains used in this study

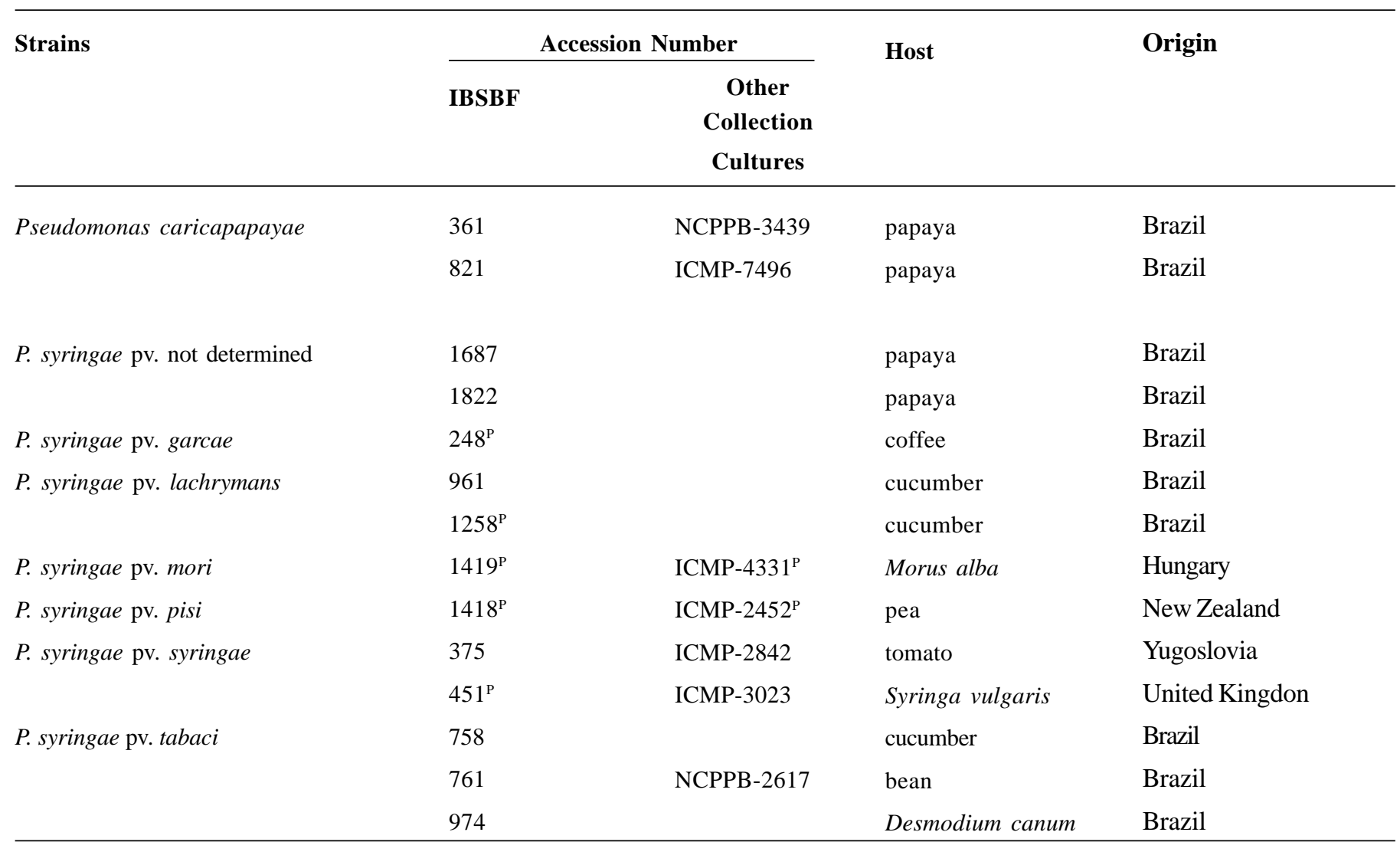

P Pathovar reference strain

IBSBF- Phytobacteria Culture Collection of Instituto Biológico, Campinas, SP, Brazil

ICMP - International Collection of Micro-organisms from Plants, Auckland, New Zealand

NCPPB - National Collection of Plant Pathogenic Bacteria, Harpenden, England

\footnotetext{
${ }^{1}$ Robbs,.C.F. Data not published.
} 


\section{Pathogenicity assays}

Papaya seedlings cv. Golden, tobacco (Nicotiana tabacum L.), bean (Phaseolus vulgaris L.) and poinsettia (Euphorbia pulcherima Willd.) plants were inoculated by infiltration with bacterial cell suspensions of papaya strain IBSBF 1687 containing ca. $10^{8} \mathrm{cfu} / \mathrm{mL}$ from $48-72 \mathrm{~h}$-old NA cultures, under moisture chamber conditions. Besides leaves, fruits, stems and flowers of papaya were also inoculated. Negative controls were inoculated with sterile distilled water. All the inoculated and controls were maintained in a greenhouse $\left(25-30^{\circ} \mathrm{C}\right)$ and examined daily for disease development. Papaya plants were also inoculated with $P$. caricapapayae strain IBSBF 361 for comparative purposes.

\section{Biochemical and physiological assays}

Biochemical tests for the identification at pathovar level were carried out according to Young \& Triggs (27) and Schaad et al. (21).

\section{Serological assays}

Bacterial suspensions (ca. $10^{9} \mathrm{cfu} / \mathrm{mL}$ ) obtained from $48 \mathrm{~h}-$ old NA cultures as well as membrane protein complex (MPC) (22) were used as antigens. Microscopy slides for double diffusion tests were prepared with $3 \mathrm{~mL}$ of $1 \%$ purified agar in phosphate buffered saline $0.1 \mathrm{M}, \mathrm{pH} 7$ with $200 \mathrm{ppm}$ sodium azide. Papaya bacterial strains were tested with antisera against $P$. syringae strains [P.s pv. syringae (AS-375), P. s. pv. tabaci (AS-761), $P$. savastanoi pv. phaseolicola (AS-736) and P. s. pv. lachrymans (AS-961)] obtained from the Antisera Collection of the Laboratório de Bacteriologia Vegetal (LBV), Instituto Biológico, Campinas, SP, Brazil. All the antigen fractions were also tested against normal serum.

\section{DNA extraction and amplification}

Genomic DNA from papaya strain (IBSBF-1687), P. syringae pv. garcae (IBSBF $248^{\mathrm{P}}$ ), P. s. pv. lachrymans (IBSBF 1258 ${ }^{\mathrm{P}}$ ), P. s. pv mori (IBSBF $1419^{\mathrm{P}}$ ), P. s. pv. pisi (IBSBF $1418^{\mathrm{P}}$ ), P. $s$. pv. syringae (IBSBF $451^{\mathrm{P}}$ ), $P$. s. pv. tabaci (IBSBF 758) and $P$. caricapapayae (IBSBF-361) were extracted (16) and the concentrations were estimated by comparison of the intensity of fluorescence emitted by known concentrations of the bacteriophage lambda DNA in an ethidium bromide-stained $0.6 \%$ agarose gel. Amplification of the 16S-23S spacer region was carried out using the primers $\mathrm{pHr}$ (12) and p23Suni322-anti (8). All PCR reactions were performed in a total volume of $25 \mu \mathrm{L}$ using $100 \mathrm{ng}$ of genomic DNA, 1.0 U Taq polymerase (Amersham Biosciences), 1 X Taq buffer, $200 \mu \mathrm{M}$ dNTPs mixture, and $0.4 \mu \mathrm{M}$ each primer. The PCR protocol consisted of a denaturating cycle of $95^{\circ} \mathrm{C}$ for $2 \mathrm{~min}$, followed by 25 cycles at $94^{\circ} \mathrm{C}$ for $1 \mathrm{~min}, 60^{\circ} \mathrm{C}$ for 30 $\mathrm{s}$ and $72^{\circ} \mathrm{C}$ for $3 \mathrm{~min}$, and a final extension of $72^{\circ} \mathrm{C}$ for $5 \mathrm{~min}$, in a thermocycler (GeneAmp PCR system 9700; Perkin-Elmer Corporation, Norwalk, Conn).

The primer set pshrp1F/2R, corresponding to $h r p L$ gene of $P$. syringae pathovars morsprunorum, pisi and syringae (4) was also tested. PCR was performed under the same conditions of the spacer regions and the amplifications were carried out by using an initial denaturation step of $95^{\circ} \mathrm{C}$ for $2 \mathrm{~min}$, followed by 25 cycles at $94^{\circ} \mathrm{C}$ for $1 \mathrm{~min}, 55^{\circ} \mathrm{C}$ for $30 \mathrm{~s}$ and $72^{\circ} \mathrm{C}$ for $1 \mathrm{~min}$, and a final extension period of $72^{\circ} \mathrm{C}$ for $3 \mathrm{~min}$. The amplification fragments were observed by electrophoresis in $1 \%$ agarose gels in $1 \mathrm{X}$
TAE buffer (0.04M tris-acetate, $0.001 \mathrm{M}$ EDTA). The gels were stained with $0.1 \mu \mathrm{g} / \mu \mathrm{L}$ of ethidium bromide and photographed under UV light using the Alpha Innotech 2200 Digital System.

PCR-RLFP of the 16S-23S spacer region and $h r p L$ gene

PCR products $(5 \mu \mathrm{L})$ were digested individually with each of the following restriction endonucleases Afa I, Alu I, Dde I, Hae III, Hpa II, Hinf I, Sau 3A I and Taq I under conditions specified by the manufacturer (Amersham Biosciences) and the restriction fragments separated by electrophoresis in $3 \%$ agarose gels using 1XTAE buffer. The gels were stained with ethidium bromide and visualized under UV. The molecular weights of the fragments were determined by comparison with a $100 \mathrm{bp}$ DNA ladder (Amershan Biosciences).

\section{RESULTS AND DISCUSSION}

Cultural, morphological, physiological and biochemical tests previously carried out by Beriam et al.(2) showed that the papaya strains belong to Pseudomonas syringae species. In this study, these strains were investigated in order to classify them at the pathovar level.

P. syringae causes diseases in a large number of plants and according to Young et al. (26) this species includes more than 50 pathovars, circumscribed on the basis of distinct host range. In addition, Young \& Triggs (27) showed that physiological and biochemical determinative tests could be used to differentiate Pseudomonas syringae at the pathovar level.

In this study, the papaya strains were pathogenic to tobacco, bean, and poinsettia. Bean and tobacco are natural hosts of P.s. pv. syringae and $P$. s. pv. tabaci, but only $P$. s. pv. tabaci was also described causing disease in poinsettia (18), suggesting that the papaya strains could be allocated as $P$. syringae $\mathrm{pv}$. tabaci. The determinative tests described in the literature (27) for identification at the pathovar level were very useful in this study (Table 2), corroborating the results of pathogenicity assays.

Another evidence that reinforced the identification of the papaya strains as $P$. s. pv. tabaci was the presence of precipitin bands only between the papaya isolates and $P$. $s$. pv. tabaci antisera in the results of the serological assays (Figure 1).

Besides biochemical, serological and pathological results, the molecular tests also confirmed the papaya strains as $P$. s. pv. tabaci. The amplification of the 16S-23S spacer region of different pathovars of P. syringae (P.s. pv. garcae, P. s. pv. lachrymans, P.s. pv. mori, $P$. s. pv. pisi, $P$. s.pv. syringae and $P$. s. pv. tabaci) resulted in a single product for all strains. The size of the product was approximately 1.1 kilobase $(\mathrm{kb})$. Only fragments ranging from 90 to 1100 base pairs (bp) obtained from restriction endonucleases experiments were considered for analysis. Several restriction enzymes were tested, but only Dde I yielded distinct profiles for each pathovar tested, which allowed to group the papaya strains with P. s. pv. tabaci (Figure 2 and Table 3).

The amplifications with the pshrp $1 \mathrm{~F} / 2 \mathrm{R}$ primers set were carried out with P.s. pv. syringae (IBSBF $\left.451^{\mathrm{T}}\right)$, P.s. pv.tabaci (IBSBF 758 and 974) and the papaya strain (IBSBF 1687) and yielded a fragment about $450 \mathrm{bp}$. No amplification was observed with $P$. caricapapayae strains. In the Alu I, Hae III, Hpa II, Hinf I, and $T a q$ I digestions, P.s. pv. syringae could clearly be differentiated from $P$. s. pv. tabaci while the papaya strains showed identical profiles to P.s. pv. tabaci (Figure 3 and Table 4). 
Table 2. Determinative tests for the papaya isolates and some Pseudomonas pathovars

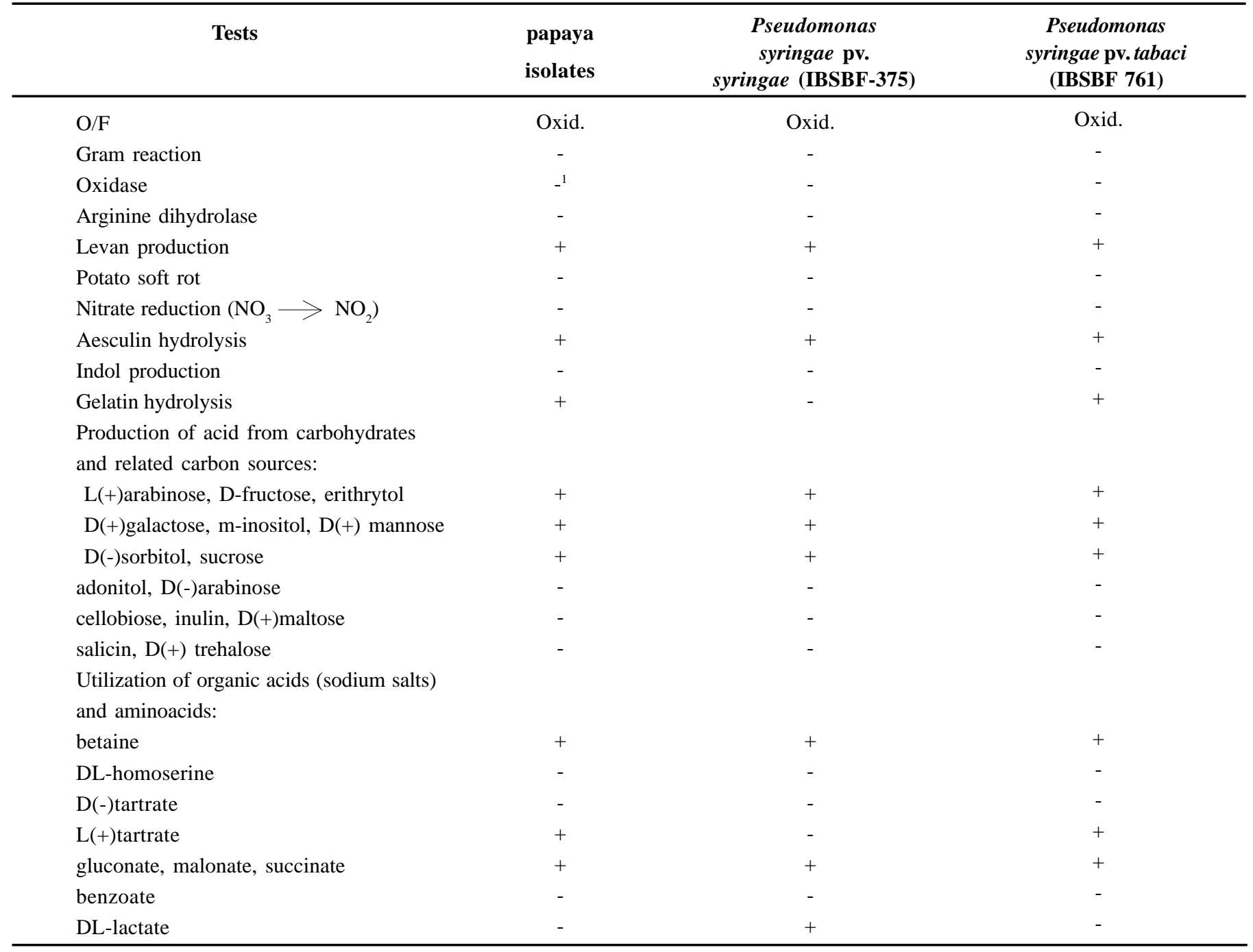

${ }^{1}$ - negative result; + positive result

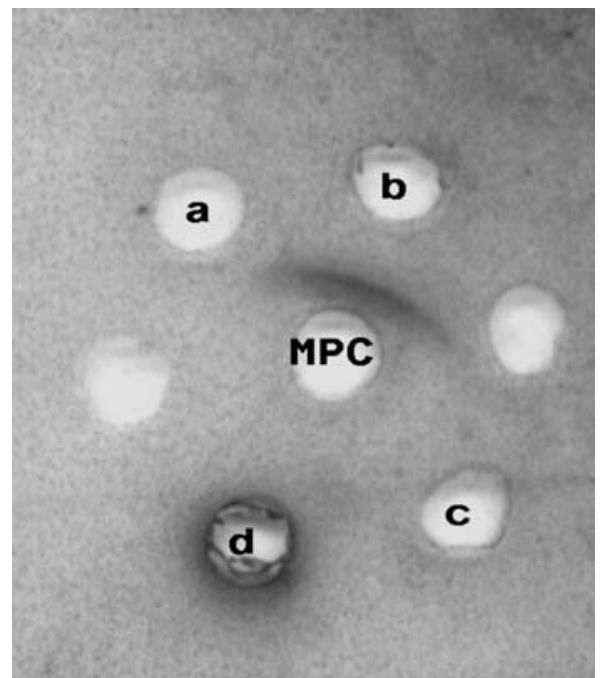

Figure 1. Serological relationship between antisera against Pseudomonas syringae pv. lachrymans (a) P.s. pv. tabaci (b), P. s. pv. syringae (d) and P. savastanoi pv. phaseolicola (c) strains and Membrane Complex Protein (MCP) of $P$. syringae from papaya.

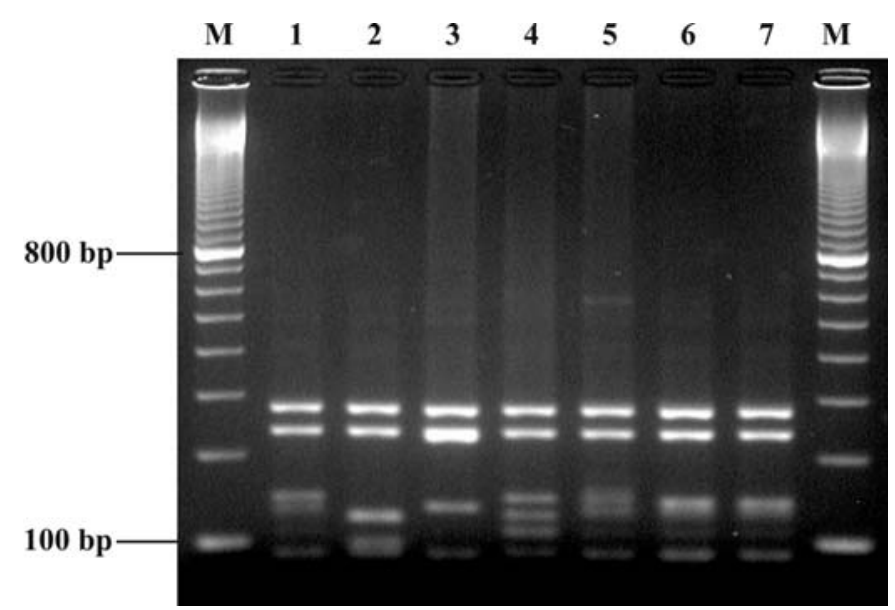

Figure 2. Restriction analysis of the $1.1 \mathrm{~kb}$ fragment of the $16 \mathrm{~S}-23 \mathrm{~S}$ rDNA spacer regions from different pathovars of Pseudomonas syringae. (M) 100 bp Marker (Amersham Biosciences); (1) P.syringae pv. garcae (IBSBF 248 ${ }^{\mathbf{P}}$ ); (2) P.syringae pv. lachrymans (IBSBF 1258 ${ }^{\mathbf{P}}$ ); (3) P.syringae pv. mori (IBSBF 1419); (4) P.syringae pv. pisi (IBSBF $1418^{\mathbf{P}}$ ); (5) P.syringae pv. syringae (IBSBF 451 ${ }^{\mathbf{T}}$ ); (6) P.syringae pv. tabaci (IBSBF 758); (7) papaya strain (IBSBF 1687). 
Specific primers have been widely used as a rapid method for identification of phytopathogenic bacteria like Erwinia amylovora (1), P. savastanoi pv. phaseolicola (17), Xanthomonas albilineans (15), X. axonopodis pv. citri (7), and others. In this study, the pshrp $1 \mathrm{~F} / 2 \mathrm{R}$ primer set exhibited specificity, discriminating P.s. pv. syringae and P.s. pv. tabaci from P. caricapapayae. Although the amplification has occurred for both P.s. pv. syringae and P.s. pv. tabaci, the restriction profiles clearly differentiated these pathovars, confirming the identification of the papaya strains as P.s. pv. tabaci.

According to Bradbury (3), strains of $P$. s. pv. tabaci can be transmitted by seeds. Denardin ${ }^{2}$ isolated P.s. pv. tabaci from papaya seed lots. Herein, the seed infection probably could be the source of primary inoculum since the papaya seedlings showed cotyledonary leaf lesions, suggesting bacterial seed transmission, which represents an important vehicle of dissemination of the disease over considerable distances.

Table 3. PCR-RFLP profiles of the spacer region $16 \mathrm{~S}-23 \mathrm{~S}$ from different pathovars of $P$. syringae produced by $D d e$ I digestion.

\begin{tabular}{ll}
\hline Strains & Fragments (bp) \\
\hline P.s. pv. garcae (IBSBF 248 $)$ & $290,240,170,160,110,90$ \\
P.s. pv. lachrymans (IBSBF 1258 $)$ & $290,240,130,100,90$ \\
P.s. pv. mori (IBSBF 1419 $)$ & $290,240,160,90$ \\
P.s. pv. pisi (IBSBF 1418 $)$ & $290,240,170,140,110,90$ \\
P.s. pv. syringae (IBSBF 451 $)$ & $290,240,180,160,110,90$ \\
P.s. pv. tabaci (IBSBF 758) & $290,240,160,150,110,90$ \\
Papaya strain (IBSBF 1687) & $290,240,160,150,110,90$ \\
\hline
\end{tabular}

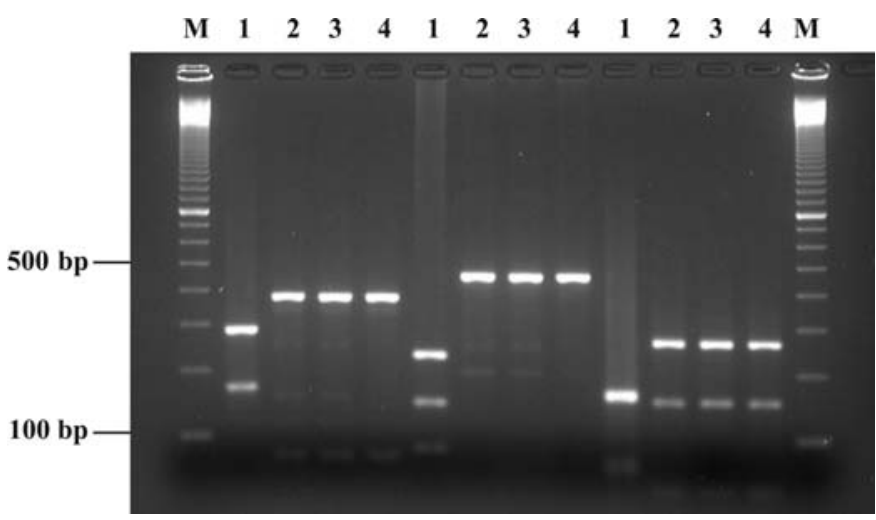

Figure 3. Restriction patterns of the $450 \mathrm{bp}$ fragment of the $h r p L$ gene from (1) Pseudomonas syringae. pv. syringae (IBSBF 451P), (2) P.s. pv. tabaci (IBSBF 758), (3) P.s. pv. tabaci (IBSBF 974), (4) papaya strain (IBSBF-1687) digested with Hae III, Hinf I and Taq I. (M) 100 bp Marker.

${ }^{2}$ N.Denardin (Universidade de Passo Fundo/RS). Data not published.
Table 4. PCR-RFLP profiles produced by digestions of the $h r p L$ gene with different restriction enzymes.

\begin{tabular}{|c|c|c|}
\hline Enzymes & Fragments (bp) & Strains \\
\hline$A f a \mathrm{I}$ & 450 & $\begin{array}{l}\left.\text { P.s. pv. syringae (IBSBF } 451^{\mathrm{T}}\right) \text {, P.s. } \\
\text { pv. tabaci (IBSBF } 758 \text { and 974), } \\
\text { papaya strain (IBSBF 1687) }\end{array}$ \\
\hline Alu I & $\begin{array}{l}200,180 \\
250,200\end{array}$ & $\begin{array}{l}\text { P.s. pv. syringae (IBSBF } 451^{\mathrm{T}} \text { ) } \\
\text { P.s. pv. tabaci (IBSBF } 758 \text { and } \\
\text { 974), papaya strain (IBSBF 1687) }\end{array}$ \\
\hline Dde I & 460 & $\begin{array}{l}\text { P.s. pv. syringae (IBSBF } 451^{\mathrm{T}} \text { ), P.s. } \\
\text { pv. tabaci (IBSBF } 758 \text { and 974), } \\
\text { papaya strain (IBSBF 1687) }\end{array}$ \\
\hline Hae III & $\begin{array}{l}290,190 \\
380,80\end{array}$ & $\begin{array}{l}\text { P.s. pv. syringae (IBSBF } 451^{\mathrm{T}} \text { ) } \\
\text { P.s. pv. tabaci (IBSBF } 758 \text { and } \\
\text { 974), papaya strain (IBSBF 1687) }\end{array}$ \\
\hline Нра II & $\begin{array}{l}400 \\
380\end{array}$ & $\begin{array}{l}\text { P.s. pv. syringae (IBSBF } 451^{\mathrm{T}} \text { ) } \\
\text { P.s. pv. tabaci (IBSBF } 758 \text { and } \\
\text { 974), papaya strain (IBSBF 1687) }\end{array}$ \\
\hline Hinf I & $\begin{array}{l}250,150,90 \\
440\end{array}$ & $\begin{array}{l}\left.\text { P.s. pv. syringae (IBSBF } 451^{\mathrm{T}}\right) \\
\text { P.s. pv. tabaci (IBSBF } 758 \text { and } \\
\text { 974), papaya strain (IBSBF 1687) }\end{array}$ \\
\hline Mbo I & 320,150 & $\begin{array}{l}\text { P.s. pv. syringae (IBSBF } 451^{\mathrm{T}} \text { ), P.s. } \\
\text { pv. tabaci (IBSBF } 758 \text { and 974), } \\
\text { papaya strain (IBSBF 1687) }\end{array}$ \\
\hline Taq I & $\begin{array}{l}170,50 \\
280,150,<50\end{array}$ & $\begin{array}{l}\text { P.s. pv. syringae (IBSBF } 451^{\mathrm{T}} \text { ) } \\
\text { P.s. pv. tabaci (IBSBF } 758 \text { and } \\
\text { 974), papaya strain (IBSBF } 1687 \text { ) }\end{array}$ \\
\hline
\end{tabular}

\section{REFERENCES}

1. Bereswill, S.; Bugert, P.; Bruchmuller, I.; Geider K. Identification of the fire blight pathogen, Erwinia amylovora, by PCR assays with chromossomal DNA. Applied and Environmental Microbiology, Washington, v. 61, p. 2636-2642, 1995.

2. Beriam, L.O.S.; Almeida, I.M.G.; Ferrari, J.T.; Grabert, E.; Barbosa, A.F.; Barbosa, I.; Louzeiro, I.M. Bacteriose em mamoeiro (Carica papaya L) causada por patovar de Pseudomonas syringae. Summa Phytopathologica, Botucatu, v.28, n.1, p.95, 2002 (Resumo).

3. Bradbury, J.F. Pseudomonas tabaci. C.M.I. Descriptions of pathogenic fungi and bacteria, n. 129, p.1-2, 1967.

4. Destéfano, S.A.L. Detecção e identificação de bactérias fitopatogênicas através da utilização de primers específicos. Summa Phytopathologica, Jaboticabal, v.26, n.1, p.158-160, 2000.

5. Frossard, P.; Hugon, R.; Verniere, C. Un dépérissement du papayer aux Antilles françaises associé à un Erwinia sp. du groupe amylovora. Fruits, Paris, v.40, n.5, p.583-594, 1985.

6. Gardan, L.; Christen, R.; Achouak, W.; Prior, P. Erwinia papayae sp. nov., a pathogen of papaya (Carica papaya). International Jour- 
nal of Systematic and Evolutionary Microbiology, Washington, v.54, n.1, p.107-113, 2004.

7. Hartung, J.S.; Daniel, J.F.; Pruvost, O.P. Detection of Xanthomonas campestris pv. citri by the polymerase chain reaction method. Applied and Environmental Microbiology, Washington, v.59, n.4, p.1143-1148, 1993.

8. Honeycut, R.J.; Sobral, B.W.S.; McClelland, M. tRNA intergenic spacers reveal polymorphism diagnostic of Xanthomonas albilineans. Microbiology, Reading, v.141, n.12, p.3229-3239. 1995.

9. King, E.O.; Ward, M.K.; Raney, E.D. Two simple media for the demonstration of pyocianin and fluorescin. Journal of Laboratory and Clinical Medicine, Milwaukee, v.44, p.301-307, 1954.

10. Leu, L.S.; Lee, C.C.; Huang, T.C. Papaya black rot caused by Erwinia cypripedii. Plant Protection Bulletin, Taichung, v.22, n.4, p.377-384, 1980.

11. Levine, M. An introduction to laboratory technique in bacteriology. New York: The Macmillan, 1954. p.68-79.

12. Massol-Deya, A.A.; Odelson, D.A.; Hickey, R.F.; Tiedje, J.M. Bacterial community fingerprinting of amplified 16S and 16S 23S ribossomal DNA gene sequences and restriction endonuclease analysis (ARDRA). In: Akkermans, A.D.L.; van Elsas, J.D.; de Brujin, F.D. (Ed.) Molecular microbial ecology manual. Dordrecht: Kluwer Academic Publishers, 1995. p. 3.3.2/1-3.3.2./8.

13. Nelson, M.N.; Alvarez, A.M. Purple stain of Carica papaya. Plant Disease, St. Paul, v.64, n.1, p.93-95, 1980.

14. Nishijima, K.A.; Couey, H.M.; Alvarez, A.M. Internal yellowing, a bacterial disease of papaya fruits caused by Enterobacter cloacae. Plant Disease, St. Paul, v.71, n.11, p.1029-1034, 1987.

15. Pan, Y.-B.; Grisham, M.P.; Burner, D.M. A polymerase chain reaction protocol for the detection of Xanthomonas albilineans, the causal agent of sugarcane leaf scald disease. Plant Disease, St. Paul, v.81, n.2, p.189-194, 1987.

16. Pitcher, D.G.; Saunders, N.A.; Owen, R.J. Rapid extraction of bacterial genomic DNA with guanidium thiocyanate. Letters in Applied Microbiology, Oxford, v.8, p.151-156, 1989.

17. Prosen, D.; Hatziloukas, E.; Schaad, N.W.; Panapoulos, N.J. Specific detection of Pseudomonas syringae pv. phaseolicola DNA in bean seed by PCR-based amplification of a phaseolotoxin gene region. Phytopathology, St. Paul, v.83, n.8, p. 965-970, 1993.

18. Ribeiro, R.L.D.; Pimentel, J.P.; Kimura, O.; Robbs, C.F.; Akiba, F. Caracterização da bactéria incitante do "fogo selvagem" da poinsettia (Euphorbia pulcherrima) no Est. Rio de Janeiro. Fitopatologia Brasileira, Brasília, v.5, n.3, p.450-451, 1980.

19. Robbs, C.F. Uma nova doença bacteriana no mamoeiro (Carica papaya $\mathrm{L}$ ). Boletim da Sociedade Brasileira de Agronomia, Rio de Janeiro, v.12, n.1/2, p.73-76, 1956.

20. Robbs, C.F.; Rodrigues Neto, J.; Malavolta Jr., V.A.; Vega, J. Uma podridão bacteriana do topo do mamoeiro causada por Erwinia sp. associada à plantas afetadas pelo vírus do mosaico, no Rio Grande do Sul. Fitopatologia Brasileira, Brasília, v.13, n.2, p.107, 1988.

21. Schaad, N.W.; Jones, J.B.; Chun, N. Laboratory guide for identification of plant pathogenic bacteria. St. Paul: APS Press, 2001. 373p.

22. Thaveechai, N.; Schaad, N.W. Immunochemical characterization of a subspecies-specific antigenic determinant of a membrane protein extract of Xanthomonas campestris pv. campestris. Phytopathology, St. Paul, v.76, n.2, p.148-153, 1986.

23. Trujillo, E.E.; Schrot, M.N. Two bacterial diseases of papaya trees caused by Erwinia species in the Northern Mariana Island. Plant Disease, St. Paul, v.66, n.2, p.116-120, 1982.

24. Ventura, J.A.; Costa, H.; Tatagiba, J.S.; Martins,D.S. Manejo de doenças e produção integrada de frutas tropicais. Fitopatologia Brasileira, Brasília, v.28, supl., p. 57-61, 2003.

25. Webb, R.R. Epidemiology and control of bacterial canker of papaya caused by an Erwinia sp. on St. Croix, U.S. Virgin Island. Plant Disease, St. Paul, v.69, n.4, p.305-309, 1985.

26. Young, J.M.; Saddler, G.S.; Takikawa, Y.; De Boer, S.H.; Vauterin, L.; Gardan, L.; Gvozdyak, R.I.; Stead, D.E. Names of plant pathogenic bacteria 1864-1995. Review of Plant Pathology, Wallingford, v.75, n.9, p.721-763, 1996.

27. Young, J.M.; Triggs, C.M. Evaluation of determinative tests for pathovars of Pseudomonas syringae van Hall 1902. Journal of Applied Bacteriology, Oxford, v.77, n.2 p.195-207, 1994. 